\title{
Remember to be Jewish: Religious Populism in Israel
}

\author{
Guy Ben Porat and Dani Filc \\ Ben-Gurion University in the Negev
}

\begin{abstract}
The paper explores the relation between religion and populism in Israel. Jewish identity has been an important marker of citizenship and belonging in Israel since its inception. The founders of the Zionist movement and the dominant elites of early statehood remained dependent upon Jewish religion to demarcate national boundaries and legitimate territorial claims. With the establishment of the state, Jewish identity helped create and legitimate a segmented citizenship regime that secured privilege for Jews. Gradually, and especially in the past two decades, Jewishness became more contested, demarcating not only Jews from non-Jews but also "authentic" Jews from allegedly "cosmopolitan elites," thus becoming part of populist politics, central to Israeli politics. The complex relation between religion and populism in Israel is demonstrated by the development of two populist parties; an "inclusive" one (Shas) and an "exclusionary" one (Likud). The study of the two parties shows the role of religious identities, tropes, and symbols in boundary-making and political strategies. In Israel, religion functions both as the positive content of the political community (the ethnos-the Jewish people-is conflated with the demos) and the demands for inclusion; and as the marker of a threat (non-Jewish citizens, asylum seekers, and allegedly disloyal secular elites).
\end{abstract}

\section{INTRODUCTION}

In 1997, during an election campaign, Benjamin Netanyahu paid a visit to Rabbi Yitzhak Kadury, an important Sepharadic religious and spiritual leader. Netanyahu was caught on tape whispering to the Rabbi's ear, 
"the left has forgotten what it is to be a Jew." The comment, directed at Israel's left/liberal parties who supported a territorial compromise, was considered inflammatory and offensive and evoked outrage. Twenty years later, in October 2017, it was Avi Gabai, then leader of the Labor Party, part of the liberal pro-peace camp, echoing Netanyahu's remark:

"People feel I am getting closer to Jewish values. We are Jewish, we live in a Jewish state. I think one of the problems of the Labor Party, seriously, is that it withdrew from it. Netanyahu told Rabbi Kadury that 'the Left forgot what it is to be Jewish'. And what the left has done in response? It forgot what it is to be Jewish. It is as if we are now only liberals. That is not true, we are Jewish and we need to talk about our Jewish values" (Ynet, 14.11.2017).

Jewish identity has been an important marker of citizenship and nationhood in Israel since its inception, an integral part of Zionism, and, more recently, part of populist politics. In this paper, we explore the relation between religion and populism in Israel. Despite Zionism's secular roots, we argue, the founders of the Zionist movement and the dominant elites of early statehood remained dependent upon, and indebted to the Jewish religion, that demarcated national boundaries and legitimated territorial claims. With the establishment of the state, Jewish identity helped create and legitimate a segmented citizenship regime that secured privilege and status for Jews. For many Jewish Israelis, Jewishness was largely a national identity with minimal or limited religious content. Gradually, and especially in the past two decades, Jewishness became more contested, demarcating not only Jews from non-Jews but also "authentic" Jews from allegedly "cosmopolitan elites."

Populism as a political phenomenon is a central characteristic of Israeli politics. From the 10 parties represented in the 21st Knesset (Israel's parliament), three-Likud, Shas, and Yisrael Beitenu—can be considered populist, summing together $40 \%$ of Parliament members. Populist movements emerge in societies where conflicts concerning the inclusion/exclusion of subordinate social groups are salient, and the signifier people become a major reference point for the constitution of political identities. It can be "inclusive," promoting the political integration of excluded social groups, or "exclusive," claiming to preserve collective subjects that feel their identity threatened. As stated in the introduction to this special issue, religion can be a way to demarcate the people's boundaries, thus, it is often related to exclusionary populism. By analyzing the Israeli 
case, we want to argue that religion may play a role in both inclusive and exclusive forms of populism.

We begin this paper with a theoretical overview of populism, followed by a discussion of the potential relations between populism and religion. Moving to our case study we describe the complex relation between religion and politics in Israel. Finally, we study two populist parties in Israel we describe as "inclusive" (Shas) and "exclusive (Likud)1; and the role of religious identities, tropes and symbols in boundary-making and political strategies. Our analysis of both parties is based on critical discourse analysis of both speeches and texts by Likud and Shas leaders. We have analyzed speeches as reported in the written media, and written texts as appear in the parties" internet home pages and social media.

\section{POPULISM}

Populism is a political phenomenon that, as Magaret Canovan so aptly put, haunts liberal democracy like a shadow (Canovan 1999). The modern notion of populism first emerged in the late 19th century, with the American People's Party and Russian Narodism. Populist movements reappeared in the mid-1900, especially in Latin America, leading mainstream political science to consider it a phenomenon typical of peripheral and semi-peripheral countries. However, the emergence of radical right populism in Western Europe in the 1990s forced scholars to rethink this idea of populism.

In different countries, populist parties have been in office, were part of government coalitions, or emerged as a significant opposition. Yet it seems that the more the word populism is used, the less clear its definition becomes. Populism has been understood as an ideology, a discourse, a disease of liberal democracy, a mobilization strategy, or a political style.

Most researchers of populism tend to view it as a "thin" ideology, a collection of ideas, often with limited internal integration, and with "a restricted core attached to a narrower range of political concepts" (Freeden 1996, 485). Those scholars argue that populism is an ideology that loosely combines a set of recurrent themes, among them, the belief in the people as the source of virtue, nostalgia for a mythical Gemeinshaft or heartland (Taggart 2000), anti-elitism, anti-intellectualism, and lack of confidence in liberal (procedural) democracy. For Mudde (2007) populism has two main themes: the view of society as divided into two antagonist groups - the pure people and the corrupted elites; 
and democracy understood solely as the expression of popular sovereignty (Mudde 2007). Mudde's definition has been widely accepted in comparative and empirical research on populism. However, when analyzing non-liberal or limited democracies, this definition fits any democratic movement, not only populist ones (Ochoa Espejo 2011).

Not satisfied with the idea of a thin ideology, other scholars define populism as a discursive strategy or frame, lacking the internal coherence that characterizes ideologies (Aslanidis 2016). This approach, however, is very similar to Mudde's, since the populist discourse is characterized as the Manichean opposition between the people and the elites (de la Torre 1997; Laclau 2005). The characterization of populism as an ideology or a discourse does not discriminate between clearly distinct movements, for example, the right-wing populisms of Le Pen or Haider, the farmers' populism in the late 19th century United States, and Latin American populism.

Scholars such as Pappas (2014) and Mueller (2016) consider populism as pathology or an antithesis of liberal democracy. Since liberal democracy emphasizes procedures as well as individual and minority rights, it limits popular sovereignty, in order to avoid the tyranny of the majorities. Somewhat ironically, against the alleged populist Manicheism they propose their own version, depicting liberalism a "good democracy" and populism "bad democracy," disregarding historical cases in which populist movements clearly broadened the boundaries of democracy.

A different approach considers populism a political strategy of a charismatic leader that uses a direct, quasi-personal manner to approach a heterogeneous mass of followers, by-passing intermediary associations (Weyland 1996). Jansen, accordingly, defines populism as "the mobilization of ordinarily marginalized social sectors into publicly visible and contentious political action, while articulating an anti-elite, nationalist rhetoric that valorizes ordinary people" (Jansen 2011, 82). However, populism may be highly institutionalized (as is the case with Peronism) and mobilize also sectors that are not marginalized (e.g., AfD, or Wilders' Party for Freedom). Finally, populism is considered as a political style, described as "the repertoires of performance that are used to create political relations" (Moffitt and Tormey 2013, 387). The populist political style is characterized by the appeal to the people, an evocation of a sense of crisis or threat, and the use of "bad manners," a coarsening of political discourse (ibid).

Taking into account the limitations of the different approaches, we propose to adopt a more complex definition, combining Mudde's, 
Laclau's (2005) and Jansen's contributions to the definition of populism. Thus, in the present paper populism will be understood as a "family" of political movements presenting alternative hegemonic projects in societies where conflicts over the inclusion/exclusion of certain social groups are central. The use of the term "people," underscoring boundaries has different meanings. According to Hermet, people can be understood as referring to the whole political community, transcending all class divisions; as synonymous with the plebs, in opposition to the elites; or as an organic, ethno-cultural unit, the Volk (Hermet 2001, 52). The polysemia of the term "people" differentiates between populism and nationalism, which are interrelated but analytically different concepts. As Brubaker (2020) states, the people is a concept that denotes both a part (the plebs as opposed to the elites) and the whole (either as the whole political community, or as an ethno-cultural unit). This double character is central to populist discourse, unlike the nation, which only denotes the whole. Secondly, the claim that the demos is the sovereign means that populism is basically democratic, while nationalism may adopt undemocratic forms ${ }^{2}$. Thus, while populism usually presents nationalist elements, not all nationalism is populist.

The ways of combining these meanings give rise to the two members of the populist family-inclusive and exclusionary populism. Movements that stress the people as "plebs" belong to the inclusive populist subfamily and those movements that understand the people mainly as an ethno-national unity belong to the exclusionary sub-family.

Inclusive populism constitutes excluded social groups as a collective subject through the claim "we are the people too," demanding political integration (de la Torre 1997), and thereby expanding democracy's boundaries. Populist inclusion, however, is always partial, since populist movements do not structurally modify the unequal distribution of resources (Betz 2001). Exclusionary populism, conversely, emerges when collective subjects act to protect an identity perceived threatened. Exclusionary populism favors the organic view of the people as an ethnically or culturally homogeneous totality, excluding migrant workers, ethnic minorities, or other groups depicted as a threat to the organic nation. This view is what researchers refer to as nativism. Cas Mudde defines nativism as "an ideology which holds that states should be inhabited exclusively by members of the native group ('the nation') and that non-native elements (persons and ideas) are fundamentally threatening to the homogeneous nation-state" (Mudde 2007, 19). Similarly for Hans-Georg Betz, nativism means the preference of the native-born over "external" groups, presenting 
itself in economic, racialized, cultural and symbolic forms; that may-but not must-be articulated with populism (Betz 2017, 2019). As Betz argues, populism cannot be reduced to nativism, for two reasons. First, populism implies anti-elitism and a sovereigntist understanding of democracy, while nativism can be elitist and/or anti-democratic. Second, nativism does not play a significant role in inclusionary populism.

Exclusive and inclusive populism share several characteristics: (1) both represent a way for social groups to actively become political subjects; (2) both attempt to resolve the inclusion/exclusion conflict by appealing to the people as homogeneous, as a source of wisdom and virtue, opposed to the corrupted elites; (3) in both cases, populist ideology intertwines three different meanings of the word people (Hermet 2001, 52); (4) in both the leader embodies the people, representing it in a seemingly unmediated and unproblematic way; (5) inclusion and exclusion take place at three different levels-symbolic, distribution of material resources, and political. Those shared characteristics explain why the inclusive and exclusionary categories are "ideal types," while in political reality the boundaries between the inclusionary and exclusionary are more blurred and fluid, as we will see below when discussing Likud and Shas parties. Understanding the people as homogeneous implies that inclusionary populism is limited to those perceived part of the people and exclusionary towards those perceived different. Understanding the people as the subject of democracy implies that even exclusionary populism must take into account groups who are not part of the "ethnos".

\section{RELIGION AND POPULISM}

"The people," is often an empty signifier that needs content for the establishment of an identity that is more than just being anti-elite or anti-foreigner (Arato and Cohen, 2017, 102). Accordingly, "populist politics also needs a convincing moral claim to trigger the self-righteous indignation necessary to construct, define and mobilize the authentic 'good' people against the alien other" (Ibid). Religion can perform an important role in populist ideology and strategy in delineating the boundaries of exclusion and inclusion and adding content and justification. Because populism, especially exclusionary, contains a strong friend/enemy logic, nativism and suspicion towards foreign ideas and people (Mudde, 2004, 16), boundaries must be defined and maintained. Thus, as Arato and Cohen explain: "Religious identity politics provide unifying content 
for the chain of equivalents in populist logic, helps moralize the friend and demonize the enemy, and to frame the elites and 'others' as immoral and corrupt, and thus part of a deeper threat to 'our' tradition that must be warded off, while providing a needed moral aura for populist politics" (2012, 108).

The relation between religion and politics extends of course beyond populism. As a social phenomenon not limited to individual belief and private spiritual preferences, religion is always political to some degree. Religious institutions in search of power can become "political," politicians in search of support can turn to religion, and religious and political institutions can compete as both claim to give authoritative answers to important questions in "oughts" and terms of commands (Ben-Porat 2013; Haynes 1998; Heclo 2001). Religion can be influential through religious institutions, parties, and the energy it provides for social movements that seek social change (Haynes 2016). The use of religion to define and defend national boundaries suggest a complex relation between the two, as well as common characteristics making nationalism, according to some, akin to religion as both provide a way of identifying and naming fundamental social groups (Brubaker 2012). Religion can be understood as contributing to the origins and development of nationalism, as deeply imbricated or intertwined with religion defining national boundaries, or supplying it with myths and symbols. It remains questionable, however, "what counts as religious language and imagery, as opposed to religiously tinged or originally religious but subsequently secularized language and imagery" (Ibid, p. 11).

Religious tropes are often used to delineate boundaries and strengthen the us-them dichotomy, even by leaders who are not religious. The use of religion might be instrumental and the religious identities are actually ethnic, serving a political cause, largely symbolic and having no religious content (Gans 1994). But, religion and ethnicity, as Mitchell (2006) suggests, often have a two-way relation. Thus, even if ethnic identities that employ religious symbols appear largely secular, they may have latent religious content that can be re-activated. Religion evokes a sense of the sacred, provides specific ideological concepts, be accompanied by powerful institutions, serve as an effective facilitator of community and provide substantive content for social boundaries. Thus, while populist leaders may evoke religious tropes and ideas, even when their own religiosity is questionable, the popular appeal of these tropes suggest it is beyond a simple "manipulation" leaders can use at will. 
Religious identity remained significant for many people, even as states were secularizing and societies modernized. Consciously or unconsciously, these sentiments can be rekindled by individuals in response to political and social changes (Mitchell 2006) and/or by political entrepreneurs seeking to advance specific goals. Once rekindled, the religious aspects of identification can become dominant, challenging hegemonies and institutional orders. As Brubaker (2012) rightly suggests, the intertwining of religious and nationalist discourse should be studied not only from the "production" side (in our case, populist leaders and parties) but also on the "reception" side, (namely, societies). Also, with religion having a wide impact, populism can be part of an existing hegemonic model, not only of counter-hegemonic ones (Arato and Cohen 2017), employing religion and religious identity as both inclusionary and exclusionary strategies. With these suggestions, we move to study populism in Israel, its relation to religion, and the changes in recent years.

\section{RELIGION AND JEWISH/ZIONIST/ISRAELI DEFINITION OF THE PEOPLE}

Conflicts concerning the inclusion/exclusion of subordinate social groups that marked Israeli society since its inception have made the signifier "people" a major reference point for the constitution of political identity, and populism, a central feature of the political system. The Zionist movement formed in the late 19th century established itself as a national movement led by Jews who rebelled against the Orthodox leadership and followed the modernization of Jewish life that began in the 18th century. National revival implied a break with the past and the attempt to replace Judaism, a religion identified with the old world, with Jewishness, a modern identity based on culture, ethnicity, a historical sense of belonging to the Jewish people and a proactive approach towards the future. The future state, in Theodor Herzl, one of the founders of Zionism, was to be one where church and state are strictly separated. Not only was religious authority rejected, a radical cultural change was also to take place as young Zionist pioneers adopted what appeared a secular way of life. Though it was largely a secular ideology, Zionism could not completely detach itself from its religious roots, as religion was indispensable as a marker of boundaries and a mobilizing force. This ambivalence toward religion could hardly be resolved, as secular nationalists would often have to acknowledge (Ben-Porat 2013). 
Secularization is a contested concept with different meanings and implications. In this work, following Chaves (1994), we treat secularization as the decline of religious authority, and the decrease in the influence of religious values, leaders, and institutions over individual behavior, social institutions, and public discourse. The influence of these processes on individual indicators of religiosity-belief or practices-remains an open question, but secularization need not imply that most individuals relinquish all their interest in religion or that religion ceases to have influence on politics and public affairs (Ben-Porat 2013). The Labor party (MAPAI) established itself as the dominant political force in pre-statehood and in the first decades of the Israeli state. Beyond its concentration of power and control of institutions, the Labor party was also able to present itself as an embodiment of Zionism itself and promoted what appeared as almost inevitable secularization. At the forefront of settlement, pioneering and self-defense, the Labor party advocated an ethos of sacrifice and commitment required for nation and state building. Politically and culturally the labor hegemony seemed to discard religion, and, more importantly, religious authority, associated with the diaspora and the Jewish acceptance of their fate, the secular pioneer and soldier becoming the model for citizenship. Labor's political hegemony enabled it, among other things, to regulate conflicts and schisms, including the religious-secular that provided different challenges.

But, Jewish religion, in spite of Labor's domination, remained central for the political life of the nation and, later, the state, contesting the very idea of secularism. First, the Zionist movement also included religious groups that shared with secular Zionists the desire to establish sovereignty. Second, more important, the Zionist claim to speak on behalf of the Jewish people encouraged it to seek wide support and forced it to make compromises on practical religious questions. Third, religion has always remained in the background as a legitimating force for Jewish territorial claims. In the process of nation-building the Hebrew culture, the alternative to religion, adopted by Zionists, and the civil religion created, reinterpreted religious texts and borrowed from traditional Jewish culture so that almost all its symbols, rites, and myths bore a religious significance. The Bible and Jewish religious tradition, after selection and reinterpretation, provided for Zionism a narrative of continuity of nationhood, connection to the land, culture, and a calendar for national life (Liebman and Don-Yehia 1984). As a result, Zionism could lend religion in its own interpretation but never completely detach itself-as it 
continued to be directed by powerful religious structures (Raz-Krakotzkin 2000; Ben-Porat, 2000).

The ambivalence of secular Zionism towards religion and practical political considerations underscore the agreements negotiated with religious political parties. The agreement known as "status quo" operated as a guideline for religious-secular negotiations during the first decades of statehood providing for a division of authority (and labor) between secular Zionism and the religious parties. The commitments were somewhat vague, but the status quo laid down a basic agreement on the Jewish character of the state of Israel (such as the respect of Sabbath and Orthodox monopoly over burial, marriage, and divorce), that enabled secular and religious political elites to formulate compromises and avoid conflicts (Don-Yehia 2000).

Explanations for the status quo often stress the political pragmatism of Ben-Gurion, accepting compromises for the sake of national unity and ensuring Labor's hegemony. Religion, however, had also an instrumental role in the formation of national identity and boundaries. The secular idea of a Jewish state referred to ethnicity or culture, but religion was the gatekeeper providing the criteria for inclusion and exclusion (Ram, 1998), reflected, among other things, in Israel's citizenship law. The majority of nonreligious Israelis disdained religious orthodoxy but continued to relate to codes, values, symbols, and a collective memory, grounded on Jewish religion (Kimmerling 2004, 354). The cooperation between Labor Party and the religious parties, akin to consociational arrangements elsewhere, was essentially a division of labor that allowed Labor to dominate foreign, security, and economic policies, in return for Orthodox monopoly over significant aspects of public life. This division of labor assigned religious institutions significant but limited authority, with Labor dominating politics for almost three decades.

Labor Zionism's hegemony evoked opposition and resistance from those who were marginalized by its ideology and practices, or offended by its disregard for religious tradition. Immigrants from the Middle East and North Africa (Mizrahim), traditionally religious, the majority of them immigrating after 1948, opposed the attempts of the state to secularize them, what the hegemonic Labor movement considered a modernization process, showing little regard for their traditions and beliefs. Mizrahim resisted secularization and developed a strategy of cultural accommodation, steering a religious path midway between Ashkenazi Orthodoxy and Ashkenazi secularism that they describe as "traditional" or masorti (Shokeid 1984). The conflict over forced secularization 
added to Mizrahims' resentment towards the Labor's elite. This resentment had also other sources, mainly the relegation of Mizrahim to peripheral development towns, unequal opportunities, and discrimination that negatively affected their social and economic status.

The end of Labor's hegemony entailed the opening of old and new religious schisms and the rise of religious populism and of populist movements with strong religious contents we describe below. The war of 1967, resulting in Israel's takeover of new territories, including the West Bank and Jerusalem, encouraged the rise of a particular new religious nationalism and to an overall intertwining of religion and nationalism. The younger generation of religious Zionists who took power after the war of 1967 was no longer willing to accept its marginal role, where security and settlement were largely "secular" affairs. Gush Emunim ("Bloc of the Faithful"), constituted an attempt by the religious Zionists to make headway into a position of leadership while fusing religion, politics, and territoriality (Schwartz 1999, 83). Religious Zionists came to believe that secular Zionism has "fulfilled its mission and finished its role" (Karpel 2003, 15) and it was now their turn to assume leadership and settle the new territories occupied in the war to ensure they would become part of a larger Israel. The national revival offered by Gush Emunim replicated many of the symbols and practices of secular Zionism but instilled them with religious meaning. The settlement project, led by the movement in the occupied territories, often bending the rules and ignoring restrictions in order to create "facts on the ground", received (at least in its early stages) sympathy and support from secular Zionists who identified with the renewal of Zionism and the pioneering collectivist spirit behind the movement.

Yet, despite its political success, establishing the settlement project, religious Zionism fell short of becoming hegemonic and failed, as of now, to "settle in the hearts." Politically, the movement remained sectorial, as witnessed in the first round of elections in 2019 when it split into two parties, one failing to cross the electoral threshold and seven seats after they re-united in the second round. Religious populism, however, has had a stronger appeal in two political parties we describe below, the Likud and Shas, employing in recent years, respectively, exclusionary and inclusive populist strategies, with strong appeal to Mizrahim. Moreover, the Likud movement exemplifies the instrumental use of religion as part of the exclusionary strategy, while for Shas religion is central to its core ideology, to the way they define the people. 
The Labor hegemony that included a division of labor concerning religion, and the attempt to create a new Jewish-Israeli culture based on a civic religion devoid of traditional religious content was challenged on both counts. First, from 1967 onwards religious parties and movements refused to be satisfied with what they perceived as a marginal role. Second, and more important to our argument here, the role religion continued to perform and its relevance for traditional society, were tools in the hands of counter-hegemonic forces that were to become dominant by the late 1970 s.

The articulation of religion as a way to define internal and external boundaries and as a recruiting or mobilizing resource in Israel has a strong resonance among a large number of Jewish Israelis. Surveys and studies of Jewish religiosity in Israel depict a complex picture of beliefs, practices, and values. Many Jewish Israelis who are not religious choose to describe themselves as "traditional" or "non-religious," rather than "secular." Even among those who identify as secular, many practice religious rituals, such as the fast on Yom Kippur and the Passover traditional Seder, and believe that circumcision is an important ritual that must be observed. The selective and partial fulfillment of religious commandments demonstrate a commitment to "Jewish popular culture" (Liebman 1997), is a conscious choice of individuals who choose to modernize but not secularize (Yadgar 2010), or result from an ethnic heritage that provides a more relaxed and flexible model of religiosity (Leon 2009). Overall, it is an evidence that religion, in spite of secularizing efforts, remained a repository of rituals and symbols available for different political causes and purposes.

The role of religion in defining the people's boundaries makes Israel nativism to be about being born within the same religion and not within the same territory. Moreover, the centrality of religion in defining the people, together with the definition of Israel as a Jewish state, makes exclusion a central characteristic of Israeli politics, not only limited to exclusionary populism ${ }^{3}$. However, as we will show in the next section, the exclusion is not just another element, but the main one in Likud's current discourse.

\section{RELIGION AS STRATEGY OF EXCLUSION: LIKUD}

The Likud party's victory in the elections of 1977 signaled the end of the Labor hegemony. The party's origins were in the opposition revisionist 
party (Herut) and its military wing, the Irgun, who challenged the pre-state Labor hegemony. In 1973, several opposition parties joined to form the Likud, under the leadership of Menachem Begin. Ideologically, the Likud presented a nationalistic worldview, in line with its founders' worldview but that also appealed to Mizrahim, excluded and marginalized by Labor's hegemony. Likud's demand for the inclusion of Mizrahim, materially and symbolically, enabled it not only to defeat Labor but also to remain in power (Filc 2006, 100-101). The rhetoric of "Jewish people" used by the Likud enabled the symbolic inclusion of Mizrachim, most of them excluded by the pre-state labor-led pioneering ethos and marginalized by the Labor elite. Menachem Begin, "located the ways in which the discourse of the Labor party formed a collective subject that did not include Mizrahim" (Ibid: 104), deconstructed the pioneering ethos and the privileges it entailed and created a space for Mizrahim in a new national ethos.

Begin's rhetoric was anti-elitist, repeatedly attacking the Labor elites for excluding both the Revisionists and Mizrahim, an exclusion that secured Labor's elite status and privileges. This anti-elitism made a significant contribution in the Likud's rise to power, able to appeal to new constituencies and take advantage of resentment, also using religion and religious discourse. In the speech presenting his new government, defeating Labor after 29 years in power, Begin stated: "We shall follow the name of our Lord forever...I announce that the government of Israel will not ask any nation...to acknowledge our right to exist...we have received that right from God" (Quoted in Filc, 2006, 118). This religious rhetoric and the use of religious symbols underscored not only the new partnership between the Likud and religious-nationalist parties but also echoed the traditionalist elements with the Likud and the rejection of Labor's alleged secularism.

For Begin, Judaism was at the same time a people and a religion, the two being inseparable. During a discussion concerning the Eitani affair, he stated "in our view concerning Judaism, there was never, and will never be, a separation between nation and religion"4 (http://www.daat. ac.il/daat/ezrachut/begin/neum24-2.htm). However, while Begin believed that in Judaism religion and national belonging are inseparable (in this he resembled the view of Orthodox Jews); he combined this view with liberal conceptions of democracy and commitment for equality. In a 1962 speech in the Knesset, for example, he rejected the claims that Arab citizens should be excluded because they do not take part in military service. "There are those saying that Arab citizens should not have full 
equal rights, since they do not fulfil equal duties. This is a strange claim. We decided not to make military service mandatory for Arab citizens. But we took that decision freely... we believe that in the Jewish state all citizens must have equal rights, without no differences of religion, nationality or origin (Knesset protocols, 20/2/62).

The Likud, however, gradually withdrew from its liberal roots and commitments as it transformed, under Benjamin Netanyahu's leadership, into an exclusionary populist party, with an anti-liberal conception of democracy, similar (albeit in many ways more extremist) to European radical right populist parties. Exclusionary populism was expressed both symbolically and politically, Netanyahu's nativist definition of the people advocated a closed ethno-national unity, threatened by foreign enemies, non-Jewish citizens, and by Jewish-Israeli opposition advocating equal citizenship. The latter were depicted as detached elites not committed to Jewish nationality and to the Jewish State. In his discourse, the identity of the people is crystal clear: "us," implies the Jewish people, defined by descent, against the anti-people marked by antisemitism. In order to characterize the "anti-people," Netanyahu builds a chain of equivalences in which the Islamic State of Iraq and Syria/Levant (ISIS) is like Iran, Iran is like Hezbollah, Hezbollah is like Hamas, Hamas is like Abu Mazen and the Palestinian Authority and all the Palestinians in the OT, the Palestinians in the OT are like the Israeli Arab citizens, and the Israeli Arab citizens are like the Israeli left, their loyalty to state and nation suspected. An example of this chain of equivalences is his statement during the 2015 election campaign:

...Hamas already declared that they will sue the state of Israel. I won't be surprised if we will hear similar things from Hezbollah, ISIS and Al Qaeda. A few days after Islamist terror committed a massacre in France, the prosecutor decided to investigate Israel that defends its citizens from the extremist Islamic terrorist organization Hamas that aims to massacre Jews. It is the same Hamas that has a pact with the Palestinian Authority. [...] (Netanyahu's Facebook wall17/1/15).

Moreover, when commenting the Security Council's 2334 decision reaffirming that the settlements in the West Bank are illegitimate, Netanyahu stated "Left parties" politicians and TV journalists were extremely pleased with the Security Council's decision; almost as the Palestinian Authority and Hamas [...]' (Netanyahu's Facebook Wall December 24, 2016). In the April 2019 elections, the Likud electoral 
campaign extended the chain of equivalences defining the "anti-people" even further. The Likud claimed that Benny Gantz, leader of the centrist party Blue and White, would "form a government with the Arab parties," as a "proof" that he was not a legitimate alternative; and accused the party of being supported by Iran.

Netanyahu uses religion in his rhetoric both to demarcate boundaries of nationhood, excluding non-Jewish citizens, and to establish hierarchies of loyalty within the Jewish nation. In 1997, during an election campaign, his words "the left has forgotten what it is to be a Jew," de-legitimized the Israeli left, equating the demand for territorial compromise with disloyalty. Under the new circumstances, what we might be witnessing is a new form of populism, possibly similar to developments elsewhere (Poland, Belgium), where religion is more instrumental and explicit than before. First, religiosity or attachment to religion becomes a litmus test for loyalty, separating authentic members of the nation from cosmopolitan and disloyal elites. Second, religious language and symbols accentuate fears and shape demands for action, to protect the nation and its borders. Third, consequently, more and more leaders, not only in the Likud, adopt religious tropes and symbols to demonstrate loyalty and garner support.

Like European radical right populist parties, Likud adopts a nativist approach defined by the boundaries of religion, further eroding the political legitimacy of Arab citizens. On the 2015 election day, Netanyahu called Jewish citizens to come out and vote because "the Israeli Arabs are galloping to the ballot boxes driven by buses paid by leftist NonGovernmental Organizations [NGO]s" (Walla News https://elections. walla.co.il/item/2838603). In the April 2019 elections, During the September 2019 elections' campaign, Netanyahu's chat boot published that "Israeli Arabs want to exterminate all of us, men women and children" (https://www.themarker.com/technation/1.7831338 11/09/19).

Recent fixation on Jewish religious-based ethnicity (Ghanem and Khatib 2017) translated to legislation initiatives undermining commitments to inclusive democracy. The "Nationality Law" of June 2018 consolidated the definition of Israel as the state of Jewish people, enshrined the (Jewish) symbols of the state, and affirmed the state's commitment to Jewish immigration and settlement. The law has not made similar commitments to equality and democracy, nor has taken into account the Arab Palestinian narrative of national belonging, hereby marginalizing Israel's Arab (and other non-Jewish) citizens. Supporters of the law explained it was a necessary measure to counteract Israel's declining commitment to 
its Jewish character, blaming among others, the liberal and elitist Supreme Court for the decline. Exclusionary and anti-elitist sentiments find support among Israeli Jews. A poll by the Israel Democracy Institute showed that many objects including Arabs in Israeli decision making, support discrimination towards Arabs and even object to Arabs living in their vicinity. The majority of Jewish respondents (61\%) supported the idea that Arab citizens' right to vote be conditioned by allegiance to Israel as a Jewish state (Ghanem and Khatib 2017). Another poll, by the Pew Research Center (2016), has shown that $48 \%$ of Israelis support the expulsion of Arabs from Israel and that Jewish citizens of different political and social backgrounds remain united in the view that Israel is the country of the Jewish people (Ghanem and Khatib 2017).

Likud's nativism is expressed also in their attacks against African asylum seekers. Likud leadership depicted asylum seekers as a threat to the Jewish character of the state, the demand for their expulsion part of an on-going demographic "battle" to ensure a Jewish majority. Minister Miri Regev, then a member of parliament, called Sudanese refugees "a cancer in the body of our nation" (Jerusalem Post 16/7/13). The fact that asylum seekers resided in poor neighbourhoods, added also a class element to the debate. Supreme Court Judges that prevented deportations, and civil society organizations providing aid to asylum seekers, were described by populist politicians as detached elites, more concerned with the welfare of strangers than of their own kin. In some instances, the support for asylum seekers was claimed to be part of a deliberate plan to undermine the Jewish identity of the state, transforming the state from "Jewish" to a state "of all citizens" (https://news.walla.co.il/item/ 3131951). When the Israeli Supreme Court ruled against a law to imprison asylum seekers Regev declared:

The court is disconnected from the people. The Court's decision is essentially calling everyone in Africa to come to Israel, because infiltrators can move around freely. The Court didn't think of the good of the Israeli public in its decision... (JP 22/9/14).

Similarly, Minister of Tourism Yariv Levin directly accused the Supreme Court of being a nest of left-wingers, opposed to the common people's interests, and caring only for "infiltrators."

Abandoning its former commitment to both nationalism and liberalism, the Likud had gradually evolved into a right-wing nationalist exclusionary populist party, where religious boundaries provide the ground for nativist 
claims and exclusion of non-Jews. In the 1970s the party's traditional approach to religion brought under its wing those alienated by the secularity of Labor's hegemony. The more recent use of religion, conversely, grounds the party's exclusionary populism.

\section{RELIGION AS THE WAY OF UNDERSTANDING WE THE PEOPLE: SHAS}

Shas emerged in 1984 as a relatively small party, representing the ultraorthodox Sephardic Jews (Jews who emigrated from Muslim countries and their descendants, also defined as Mizrahim). Since then it has evolved into a populist party that puts forward radical claims for the inclusion of Sephardic Jews, together with an exclusionary stance towards nonJews, stemming from an orthodox interpretation of Judaism. Under Rabbi Ovadia Yosef (Israel's Sephardic Chief Rabbi between 1973 and 1983) and Aryeh Deri's joint leadership, Shas became one of Israel's most important political parties in the 1990s. The party's constituency comprises an ultra-orthodox core and a traditionalist periphery as the bulk of its voters are lower class Mizrahim (Peled 1998).

The party's two central goals are "Restoring the Crown-of the Torah-to its Ancient Glory", and advancing social justice (Shas Homepage). Restoring the Crown to its Ancient Glory" is first and foremost an ethnic matter, raising the status and stature of the Mizrahi identity and culture in Israel" (Yadgar 2003). Shas' populism is built around three Manichean oppositions between "us and them" — Sephardic religious versus secular Jews, Mizrahim versus Ashkenazim, and Jews versus non-Jews. For Shas, Jewish religious and national belonging conflate, there is no national existence outside religion. Shlomo Benizri (a former Shas leading politician) stated that "Israel is a nation only through the Torah" (Benizri, Shas Homepage). Shas' vision of the political, of democracy, and of politics is profoundly anti-liberal. In accordance with traditional religious views, its leaders do not believe in the separation of spheres-personal and political, state and civil society, state and church. Religion is an inseparable part of the public sphere and, consequently, state institutions should be subordinated to religious authority.

Like all populist movements, Shas is anti-elitist, condemning both ultraorthodox Ashkenazim for their discrimination against Mizrahi students and rabbis, and the secular Ashkenazi elite for the exclusion and marginalization of Mizrahi Jews. 
When Arieh Dery was prosecuted and condemned for bribery, Shas transformed its leader's investigation and trial into an indictment of the Ashkenazi establishment, and especially of the judicial and media elites. In the 2015 elections' campaign, Shas presented itself as the champion of the "transparent" people, the poor and the marginalized, opposing them to the affluent middle classes (Mako 2015). It should be noted that, as is the case also for Khomeinism, in religious populist movements sectors among the religious hierarchy play a leading role. This is in line with Torcuato diTella's observation (1965) that many populist movements are led by what he called secondary (alternative) elites; while challenging the dominant elites, thus playing an anti-elitist role in society as a whole.

Shas puts forward inclusive steps in the symbolic, political, and material dimensions with the aim of replacing what is perceived as exclusionary secular European Zionism, with a model of Israeliness rooted in the Sephardic religious worldview. Symbolic inclusion is both religious-the Sephardic religious view vis-à-vis the dominant Ashkenazi ultra-orthodox conception; and cultural-Mizrahi culture as part of Israeliness. Shas' leader, Rabbi Ovadia Yosef, aimed to transform Yosef Karo's old Sephardic interpretation of the sacred texts into the dominant interpretation in present-day Israel. Shas' cultural, religious, and political institutions are part of this effort, a "religious revolution" in its members' words (Tessler 2003). Thus, according to Shas' leaders, Jewishness, rather than (secular) Israeli values or attitudes, must be the gateway to participation in Israeli society (Peled, ibid). In the first interview he gave after his imprisonment ended, Deri voiced his challenge to the dominant secular Ashkenazi view of Israeliness:

They claim that they are Israeliness. They took over Israeliness, they want to be the ones who determine the agenda for being Israeli. They want to decide what an Israeli has to look like, and anyone who does not adhere to their style and standards is not a "true" Israeli; he is a fanatic, a Mizrahi, a fool. (Ben Hayiim 2002).

When asked by the interviewer as to what alternative there was, Deri answered,

\footnotetext{
'A people. The Jewish people. With our Torah, with our culture. Of course, with all the modern improvements we can have. But why should I be ashamed of being Mizrahi?..."Which tradition did they bring here, the ills of American culture?"
} 
Shas functions as an inclusive populist movement for Mizrahim not only at the symbolic level. The party participated in both national and local elections, becoming a platform for the political empowerment of Mizrahim. The party's economic agenda was often contradictory, ideologically supporting the welfare state but in practice being part of most governmental coalitions since the neoliberal turn in the mid-1980s. Although the party claims that it conditioned its participation on the implementation of measures such as the increase in transference payments and that it opposed regressive measures such as charging VAT on fruit and vegetables or "across the board" budget cuts; Shas was de facto a full, albeit reluctant, partner in the neoliberal transition.

Shas functions not only as a populist inclusive movement but also as an exclusionary populist movement, in line with the ultra-orthodox definition of Judaism. As discussed above, the definition of the Jews as the chosen people and a narrow, biological understanding of Jewish belonging (based on matrilineal descent) ${ }^{5}$ combine to produce an ethnocentric approach to social life. This underscores a Manichean approach that divides the world into "the good [Jewish] people" and the dangerous or evil "others," namely the secular liberal elites that threaten the (religious) Jewish character of the state, and the non-Jews who embody the danger of assimilation and loss of religious/national purity (Leon 2014). Thus Shas, like the Likud, directs its attacks mainly against migrant workers and particularly against African asylum seekers, either Muslim or Christians. As Rabbi Moshe Shafir (a Shas cadre) has written in the party's newspaper, by their very presence they represent the threat of assimilation, "a threat to the institution of marriage, to the decent family" (Shafir 2012).

Shas understands solidarity and redistribution as limited to those who belong to the Jewish people and adopts a welfare chauvinist approach to social rights. Migrant workers must be limited in numbers and allowed to stay for relatively short periods and asylum seekers should be sent back to their countries of origin. When former Shas' chairperson Eli Yishai was in charge of immigration policy in his capacity as Minister of Internal Affairs (2009-2013), he declared that he will "keep fighting until we send the last of the "infiltrators" [the pejorative name chosen by the Israeli right to refer to asylum seekers] back to their countries of origin (Yishai 2012)." In a radio interview, he claimed that "if [...] we receive hundreds of thousands of "infiltrators" that will be the end of the state of Israel” (Yishai 2013).

Interestingly, while non-Jews, on the whole, are attacked since they do not belong to the people, Shas' approach to Israel's Arab citizens is more 
nuanced, sharing similar economic burdens and concerns. Thus, while Shas members have been very active in their opposition to mixed neighborhoods (Leon ibid), Deri proclaimed that Mizrahi Jews and Israeli Arabs share common interests. During the 2013 electoral campaign, Deri invited Israeli Arabs to consider Shas as their political home, adding that, "[...] unfortunately most Israeli Arabs live in deprivation... we are the party that cares for people like them. Israeli Arabs want to preserve their tradition, and we (Mizrahim) want to preserve ours" (Novick 2012). ${ }^{6}$

Religion has played both an inclusive and an exclusionary role in the politics of Shas. The party emerged as a populist inclusive movement in which the Sephardic religious worldview represented the ground for claims for inclusion, reaching out to the Sephardic economic lower classes "by stressing a message of Jewish unity rooted in religious values" (Kopelowitz 2001). However, the specific characteristics of the ultra-orthodox religious view underscore a nativist exclusionary conceptualization of the people. In a society like Israel which is characterized by a multi-layered structure of different degrees of inclusion and exclusion, Shas plays an inclusive role for Mizrahim, while adopting extreme exclusionary and xenophobic rhetoric and policies towards the non-Jew "other," mainly embodied by African asylum seekers.

\section{CONCLUSIONS}

Both inclusive and exclusionary populist movements, share a friend/ enemy distinction posed as a confrontation between the "people" and "others," elites, immigrants and/or minorities. The people, however, is not a self-evident subject as its composition is ever-changing and contested, and boundaries are constantly challenged. Religion, as stated in the introduction of this special issue, can be instrumental for drawing boundaries and essential for populist movements. In Israeli, religion is of special significance due to historical (and theological) lack of separation between the Jewish people and the Jewish religion. As argued above, secular Zionism, in spite of its declared rebellion against religious authority, could never fully detach itself from religion. Thus, religion functions both as the positive content of the political community (since the ethnos - the Jewish people-is conflated with the demos); and as the marker of a threat (non-Jewish and their allies among the secular elites). However, this double use of religion is not uniform and answers 
to various social and economic changes. As we saw above, the Likud party, in line with what was described as "exclusive populism," uses religion mostly in an instrumental way, as a marker of a threat, as a way to build a chain of equivalences between different Muslim enemies and its allies among the secular left. On the other side, for Shas, the Mizrahi religious party, in line with what was described as "inclusive populism," religion functions principally as the content of their identity, and as their way to claim for inclusion of Mizrahim.

While the particular characteristics of the historical relation between religion and people in Judaism make the Israeli case singular, we still consider that its study can draw more general insights, particularly, in terms of the complex interplay between religion and the inclusive and exclusionary forms of populism. Religion not only functions as an excluding boundary or as the marker of a threat but also as a way to claim to be included. Such was religion's function for Mizrahim in Israel, both during the period in which Menachem Begin led the Likud, and in the case of Shas. In order to better understand the conditions of possibility of religion grounding inclusive or exclusionary forms of populism further research must be done.

\section{NOTES}

1. Israel Beitenu is also an exclusionary populist non-religious party, not analyzed here since it is much smaller than Likud.

2. See also De Cleen 2017.

3. Thus, Israel's main opposition party in the last three elections, Kahol Lavan, committed itself not to form a governmental coalition with the United Arab List.

4. Rina Eitani was an Holocaust survivor, member of Nazrat Illit's city council for the Labor party in the mid-Sixties. When it was published that her mother was a Christian German, the Ministry of Internal Affairs changed his national belonging from "Jew", to "non-Jew".

5. While conversion is possible in principle, ultra-orthodox Jews discourage it.

6. This approach was reflected in the results of the 2013 elections. Shas was the non-Arab party which got the most votes among Israeli Arabs. Shas' success was especially significant among the Bedouins in southern Israel. One of the local family leaders, Suliman Tarabin, explained their support for Shas as resulting from the fact that "they are the only party that supports the lower classes... Only Shas took care of the Bedouins, they are religious, they are credible and they care for the weak". (from Yagna, Yanir, "When the Bedouin Vote, They Often Vote Shas", Haaretz, 27 January 2013, http://www.haaretz.com/news/israeli-elections-2013/when-the-bedouin-vote-theyoften-vote-shas.premium-1.496401 (last accessed September 13, 2013)).

\section{REFERENCES}

Arato, A, and JL Cohen. 2017. "Civil Society, Populism and Religion.” Constellations 24:283-295. 
Aslanidis, Paris. 2016. "Is Populism an Ideology? A Refutation and A New Perspective." Political Studies 64:88-104.

Ben-Porat, Guy 2000. "In a State of Holiness." Alternatives 25:223-246.

Ben-Porat, Guy. 2013. Between State and Synagogue: The Secularization of Contemporary Israel. Cambridge: Cambridge University Press.

Ben Hayiim, Avishai. 2002. "Interview with Aryeh Deri." Ynet. www.ynet.co.il/articles/ 0,7340,L-2099674,00.html (Hebrew) (last accessed 13 Sept. 2013).

Betz, Hanz-Georg. 2001. "Exclusionary Populism in Austria, Italy and Switzerland." International Journal 56(3):393-420.

Betz, Hanz-Georg. 2017. "Nativism Across Time and Space." Swiss Political Science Review 23:335-353.

Betz, Hanz-Georg. 2019. "Facets of Nativism: A Heuristic Exploration." Patterns of Prejudice 53:111-135.

Brubaker, Rogers. 2012. "Religion and Nationalism: Four Approaches." Nations and nationalism 18(1):2-20.

Brubaker, Rogers. 2020. "Populism and Nationalism." Nations and Nationalism 26:44-66.

Canovan, Margaret. 1999. "Trust the People! Populism and the Two Faces of Democracy." Political Studies 47:2-16.

Chaves, Mark 1994. "Secularization as Declining Religious Authority." Social Forces 72 (3):749-774.

De Cleen, B. 2017. "Populism and Nationalism." In Oxford Handbook of Populism, eds. C. Rovira Kaltwasser et al. Oxford and New York: Oxford University Press, 342-362.

De la Torre, Carlos. 1997. "Populism and Democracy: Political Discourse and Culture in Contemporary Ecuador." Latin American Perspectives 24:12-25.

Don-Yehia, Eliezer. 2000. "Conflict Management of Religious Issues: The Israeli Case in A Comparative Perspective." In Parties, Elections and Cleavages, eds. R. Hazan and M. Maor. London: Frank Cass, 85-108.

Filc, Dani. 2006. Hegemony and Populism in Israel. Tel Aviv: Resling, (Hebrew).

Freeden, Michael. 1996. Ideologies and Political Theory: A Conceptual Approach. Oxford: Oxford University Press.

Gans, Herbert J. 1994. "Symbolic Ethnicity and Symbolic Religiosity: Towards A Comparison of Ethnic and Religious Generation." Ethnic and Racial Studies 17 (4):577-592.

Ghanem, As' ad, and Ibrahim Khatib. 2017. "The Nationalisation of the Israeli Ethnocratic Regime and the Palestinian Minority's Shrinking Citizenship." Citizenship Studies 21 (8):889-902.

Haynes, Jeff. 1998. Religion in Global Politics. London and New York: Longman.

Haynes, Jeff. 2016. "Introduction." In Routledge Handbook of Religion and Politics, ed. Haynes. UK: Routledge.

Heclo, Hugh. 2001. "Religion and Public Policy: An Introduction." Journal of Policy History 13:11-18.

Hermet, Guy. 2001. Les Populismes Dans Le Monde. Une Histoire Sociologique XIXe-XXe Siècle. Paris: Fayard.

Jansen, Robert S. 2011. "Populist Mobilization: A New Theoretical Approach to Populism." Sociological Theory 29:75-96.

Karpel, Motti. 2003. The Revolution of Faith: The Decline of Zionism and the Religious Alternative. Alon Shvut: Lechatchila, (Hebrew).

Kimmerling, Baruch. 2004. Immigrants, Settlers, Natives: The Israeli State and Society Between Cultural Pluralism and Cultural Wars. Tel-Aviv: Am Oved, (Hebrew).

Kopelowitz, Ezra. 2001. "Religious Politics and Israel's Ethnic Democracy'." Israel Studies 6(3):166-190. 
Laclau, Ernesto. 2005. The Populist Reason. London: Verso.

Leon, Nissim. 2009. "A Post-Orthodox View on Mizrachi Traditionalism." Pe'amim 122 (123:89-115, (Hebrew).

Leon, Nissim. 2014. "Ethno-religious Fundamentalism and Theo-Ethnocratic Politics in Israel." Studies in Ethnicity and Nationalism 14(1):20-35.

Liebman, Charles. 1997. "Prospects for Jewish Secularism." Alpayim 14:97-115, (Hebrew).

Liebman, Charles, and Eliezer Don-Yehia. 1984. "Traditional Culture in A Modern State: Changes and Developments in the Civil Religion of Israel." Megamot 24(4):461-485, (Hebrew).

Mako. 2015. http://www.mako.co.il/news-military/politics-q1_2015/Article-b640a73be2dfa 41004.htm (last accessed 17/2/2020).

Mitchell, Claire. 2006. "The Religious Content of Ethnic Identities." Sociology 40 (6):1135-1152.

Moffitt, Benjamin, and Simon Tormey. 2013. "Rethinking Populism: Politics, Mediatisation and Political Style." Political Studies 62(2):381-397.

Mudde, Cas 2004. "The Populist Zeitgeist." Government and Opposition 39:541-563.

Mudde, Cas. 2007. Populist Radical Right Parties in Europe. Cambridge: Cambridge University Press.

Mueller, Jan-Werner. 2016. What is Populism. Philadelphia: University of Pennsylvania Press.

Novick, Akiva. 2012. “Deri's Shas Party Conference.” Ynet. http://www.ynet.co.il/articles/ 0,7340,L-4301965,00.html (Hebrew), 2012 (last accessed 13 Sept. 2013).

Ochoa Espejo, Paulina. 2011. The Time of Popular Sovereignty: Process and the Democratic State. Philadelphia, PA: Pennsylvania State University Press.

Pappas, Takis S. 2014. Populism and Crisis Politics in Greece. Basingstoke: Palgrave.

Peled, Yoav. 1998. "Towards A Redefinition of Jewish Nationalism in Israel: The Enigma of Shas." Ethnic and Racial Studies 21(4):703-727.

Pew Research Center. 2020. Israel's Religiously Divided Society. Washington, DC.

Ram, Uri 1998. "Why Secularization Fails? Secular Nationalism and Religious Revivalism in Israel." International Journal of Politics, Culture and Society 21:57-73.

Raz-Krakotzkin, Amnon. 2000. "Rabin's Legacy: On Secularism, Nationalism and Orientalism." In Contested Memory: Myth, Nationalism and Democracy, ed. L. Grinberg. Beersheba: Humphrey Institute, Ben-Gurion University, 89-107.

Schwartz, Dov. 1999. Religious Zionism: Between Rationality and Messianism. Tel-Aviv: Am-Oved, (Hebrew).

Shafir, Moshe. 2012. "Open Letter." Yom le Yom 1/6/12, http://www.yomleyom.co.il/ BRPortal/br/P103.jsp?cat=217358 (Hebrew).

Shokeid, Moshe. 1984. "Cultural Ethnicity in Israel: The Case of Middle Eastern Jews' Religiosity." AJS Review 9(2):247-271.

Taggart, Paul. 2000. Populism. Buckingham: Open University Press.

Tessler, Ricki. 2003. In the Name of God: Shas and the Religious Revolution. Jerusalem: Keter, (Hebrew).

Weyland, Kurt. 1996. "Neopopulism and Neoliberalism in Latin America: Unexpected Affinities." Studies in Comparative International Development 31:3-31.

Yadgar, Yaakov. 2003. "Shas as A Struggle to Create A New Field: A Bourdiean Perspective of an Israeli Phenomenon." Sociology of Religion 64(2):223-246.

Yadgar, Yaakov. 2010. Masortim in Israel: Modernity Without Secularization. Tel-Aviv: Shalom Hartman Institute, Bar-Ilan University, and Keter, (Hebrew).

Yishai Eli. 2012. http://www.ynet.co.il/articles/0,7340,L-4288197.00.html (last accessed May 13, 2014). 
Yishai, Eli. 2013. "Infiltrators Will Return, Every Last One.” Mako. http://www.mako.co. il/news-military/politics/Article-74bb292eddc1431017.htm (last accessed 13 Sept. 2013).

Guy Ben-Porat is a professor at the Department of Politics and Government at Ben-Gurion University. He is the author of Between State and Synagogue, the Secularization of Contemporary Israel (Cambridge University Press, 2013).

Dani Filc is a Professor at the Department of Politics and Government, Ben-Gurion University. Some of his publications are Hegemony and Populism in Israel, Circles of Exclusion: The Politics of Health-Care in Israel, and The Political Right in Israel: The Many Faces of Israeli Populism. 